\title{
Ultrastructural Organization of Cystidia in the Basidiomycete Agrocybe praecox
}

\author{
By K. GULL AND R. J. NEWSAM \\ Biological Laboratory, University of Kent, Canterbury CT2 $7 \mathrm{NJ}$
}

(Received 16 January 1975)

\begin{abstract}
SUMMARY
Cystidia of the gill hymenium in the fruit body of Agrocybe praecox show a distinct ultrastructural differentiation. They are large coenocytic cells and lack the glycogen-like storage reserves of the adjacent basidia. Cystidia contain large amounts of smooth endoplasmic reticulum. Their ultrastructure suggests a role as a secretory cell; the nature and function of the secretory product is discussed.
\end{abstract}

\section{INTRODUCTION}

The hymenial layer of the gills of many basidiomycete fruit bodies contains two major cell types: basidia and cystidia (Burnett, I968; Talbot, I97I ; Webster, I970). Basidia are the hyphae in which meiosis occurs and which eventually produce the basidiospores. Cystidia are termed sterile since they do not produce basidiospores; they are usually larger than basidia and can occur in various locations on the gill face and edge. Structure and arrangement of cystidia at the light-microscope level are important taxonomic criteria. Even though cystidia represent an obviously important hyphal differentiation their function in the fruit body remains unclear. This paper describes the ultrastructural organization of cystidia in Agrocybe praecox. The ultrastructural differentiation found in cystidia is contrasted with that of basidia, and the possible function of cystidia discussed.

\section{METHODS}

Fruit bodies of Agrocybe praecox were collected from the campus of the University of Kent. Small pieces of gill tissue were removed and fixed in $2.5 \%(\mathrm{w} / \mathrm{v})$ glutaraldehyde in cacodylate buffer $\mathrm{pH} 7 \cdot 4$. Samples were post-fixed in $1 \%(\mathrm{w} / \mathrm{v})$ osmium tetroxide in veronalacetate buffer, $\mathrm{pH} 7 \cdot 2$, dehydrated in a graded ethanol series and embedded in Spurr's resin (Spurr, 1969). The tissue was flat-embedded so that orientation of gills allowed longitudinal sections of basidia to be cut. Sections were cut with glass knives using an LKB ultratome III and stained with uranyl acetate and lead citrate. Sections were viewed in an AEI 80 I A electron microscope at an accelerating voltage of $60 \mathrm{kV}$. Light-microscope sections, I $\mu \mathrm{m}$ thick, were cut from epoxy-embedded material. They were stained in $\mathrm{I} \%$ $(\mathrm{w} / \mathrm{v})$ toluidine blue and examined in a Reichert Zetopan microscope.

\section{RESULTS}

Light-microscope survey sections of Agrocybe gills clearly showed the presence of large cystidia amongst the hymenial basidia (Fig. I). Basidia of Agrocybe are about 4 to $6 \mu \mathrm{m}$ long and 2 to $3 \mu \mathrm{m}$ wide. They are very closely arranged along the gill edge (Fig. I). The cystidia are much larger, elongate cells arising from hyphae in the sub-hymenial layer. 

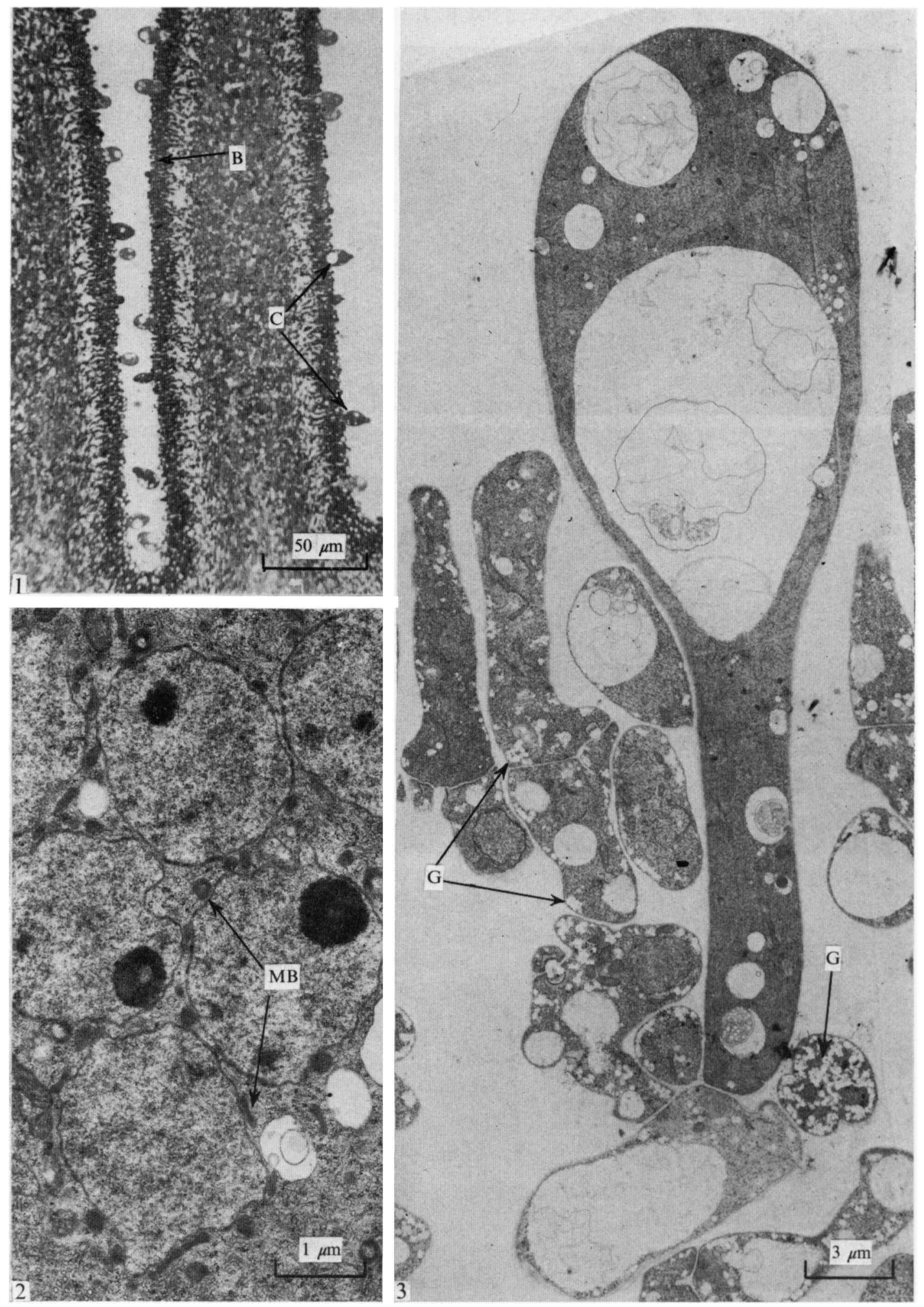

Fig. I. Light micrograph of a gill, showing the relationship between the cystidia (C) and basidia (B) of the hymenium.

Fig. 2. Electron micrograph of a portion of a cystidium, showing six nuclear profiles. Note the association of microbody-like organelles (MB) with the nuclear envelope.

Fig. 3. Low-power electron micrograph of a cystidium. The cystidium arises from a hypha in the sub-hymenial layer; it lacks the glycogen-like reserves $(G)$ of the basidia. 

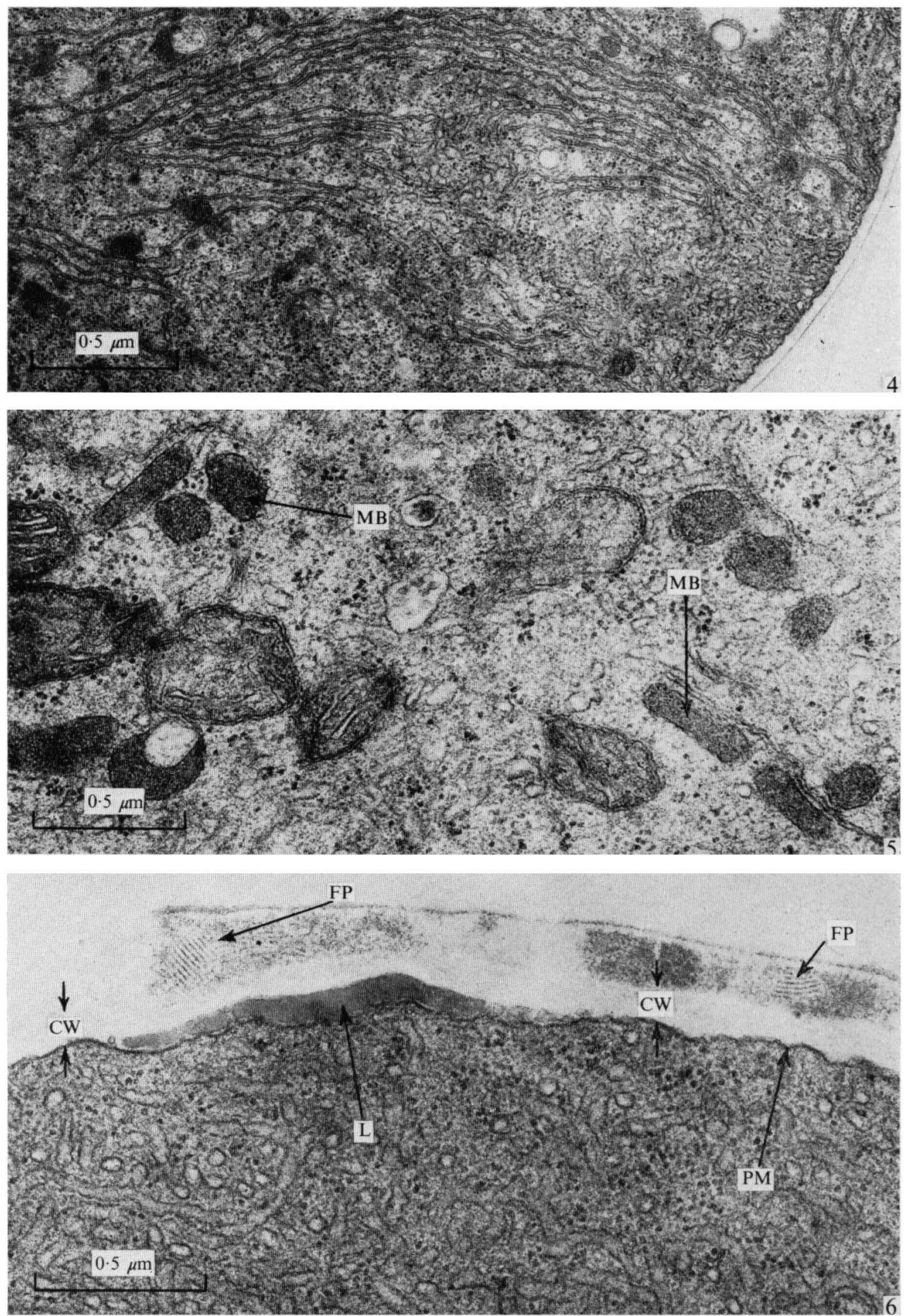

Fig. 4. Electron micrograph of cystidial cytoplasm showing different arrangements of the smooth endoplasmic reticulum.

Fig. 5. Electron micrograph of microbody-like organelles (MB) in the cystidial cytoplasm.

Fig. 6. Electron micrograph of a peripheral region of a cystidium near the apex. Note the lipid (L) between the cell wall (CW) and protoplasmic membrane (PM). The encrusting material sometimes shows a fingerprint pattern (FP). 
The lower portion of the cystidium within the gill, is about 2 to $3 \mu \mathrm{m}$ in diameter. Much the larger part of the cystidium lies in the inter-gill space (Fig. I). This region of the cystidial cell is expanded (often Io to $15 \mu \mathrm{m}$ diameter), though sometimes it again tapers to a rounded apex.

Cystidia were often vacuolate (Figs I and 3) and were always multinucleate. Six to eight nuclear profiles per cystidial cell were often encountered. The nuclei were usually clustered (Fig. 2). Nucleoli of the cystidial nuclei lacked a well-developed granular zone and were mainly composed of a fibrillar zone.

The most striking ultrastructural characteristic of cystidia was the large amounts of smooth endoplasmic reticulum present in the cytoplasm. Most of the background cytoplasm of the cystidium showed this network of branching, tubular, smooth-membraned reticulum (Figs. 4, 5 and 6). At certain points the membranes of this reticulum were aligned parallel to each other in short stacks or as long strands (Fig. 4). This remarkable concentration of smooth endoplasmic reticulum was peculiar to cystidia and was not found in any other cell type in the Agrocybe gill.

The other characteristic organelle of the cystidial cytoplasm was a microbody-like structure. The contents of these organelles had a uniform electron density and were bounded by a single membrane. Such microbody-like structures were often closely associated with both the smooth endoplasmic reticulum (Fig. 5) and the nuclear envelope (Fig. 2).

Basidia of Agrocybe contained accumulations of glycogen-like material (Fig. 3). Such aggregations were not seen in the adjacent cystidia.

The narrowed apex of the cystidia often showed regions of lipoid material. Sometimes such aggregations of lipid were on the outside of the cystidium wall, whilst at other times the lipid was observed between the plasma membranes and the cystidium wall (Fig. 6). Encrusting material on the outside of the wall at the apex sometimes had a 'fingerprint' pattern (Fig. 6).

\section{DISCUSSION}

The form of structural differentiation shown by cystidia of Agrocybe is extremely unusual amongst fungal cells. The differences between cystidia and basidia in Agrocybe are very marked. Cystidia are large, coenocytic cells, lacking the glycogen-like aggregations characteristically found in the basidia. Their most unusual feature, however, is the high concentration of smooth endoplasmic reticulum.

Ultrastructurally, cystidia of Agrocybe show some important similarities to the cystidia of Strophoria rugosoannulata (Thielke, 1972). Large stacks of smooth-membraned strands were found in Stropharia by Thielke (1972). Such large concentrations of smooth endoplasmic reticulum are suggestive of a secretory function for the cell. It is difficult to determine if the lipid material found at the apex of cystidia represents ultrastructural accumulations of the secretory product, or is merely a by-product of the cells' metabolism. It is well known, however, that many types of cystidia have material encrusted on their apices (Burnett, 1968; Talbot, 1971; Webster, 1970).

We have found no evidence for a Golgi- or vesicle-mediated secretory process. We feel that the stacks of smooth-membraned cisternae are merely aligned, smooth, endoplasmic reticulum rather than a true dictyosome.

Ultrastructurally, cystidia of Agrocybe resemble certain types of mammalian cell. Possession of large amounts of smooth endoplasmic reticulum is characteristic of mammalian cells synthesizing steroid hormones - the interstitial cells of testis, cells of corpus luteum and adrenal cortex (Fawcett, 1966). 
If cystidia of basidiomycetes can be classified as secretory cells then the question of the nature and function of the secretory product is raised. Thielke (1972) states that in Stropharia cystidia are formed early in the development of the hymenium. It may be, therefore, that the secretory product performs some role in hymenial differentiation. Alternatively, a lipid-based secretory product may be involved in the production of a hydrophobic gill surface.

\section{REFERENCES}

BURNeTt, J. H. (1968). Fundamentals of Mycology. London: Edward Arnold.

FAwCETT, D. W. (1966). The Cell. Philadelphia and London: W. B. Saunders.

SPURR, A. R. (1969). A low-viscosity epoxy resin embedding medium for electron microscopy. Journal of Ultrastructure Research 26, 31-43.

Talbot, P. H. B. (197I). Principles of Fungal Taxonomy. London: MacMillan.

Thielke, C (1972). Zisterneaggregation bei höheren Pilzen. Protoplasma 75, 335-339.

WeBster, J. (1970). Introduction to Fungi. Cambridge: Cambridge University Press. 